DOI: $10.12957 / \mathrm{e}-\mathrm{mosaicos} .2020 .53061$

\title{
ENSINO MÉDIO: UM DEBATE NECESSÁRIO
}

\section{Caríssimos/as Leitores/as,}

Em 2019 publicamos o dossiê temático "Ensino Médio: passos e impasses na atualidade", organizado pelos professores Gaudêncio Frigotto e Marise Ramos. Muitas propostas de artigos haviam chegado à e-Mosaicos e a decisão editorial, em conjunto com os organizadores, foi a de darmos continuidade ao trabalho em 2020.

Designamos para essa vigésima primeira edição de e-Mosaicos a publicação da parte II desse dossiê temático. Para nós, a quantidade de submissão de textos recebidos e sua qualidade, refletem a importância e a urgência do debate sobre os desafios e impasses que se apresentam para o Ensino Médio na atualidade, dentro do cenário da educação brasileira.

Os artigos refletem, em seu conjunto, a trajetória histórica do Ensino Médio, o viés da formação docente e, também, como se configura essa etapa da educação básica, seja no que se refere ao Ensino Médio como formação geral, seja no que se refere ao debate com a Educação Profissional e com o Ensino Médio Integrado.

Como afirmamos no editorial da parte I do dossiê temático, esse é um debate mais do que necessário. Os artigos que compõem essa edição possibilitam, mais uma vez, a reflexão e o diálogo sobre o lugar do Ensino Médio, suas potencialidades, a partir de abordagens que consideram a legislação e as políticas públicas para o Ensino Médio, os desafios do Ensino Médio Integrado, a gestão da educação, além de abordagens que dialogam com a rede Federal e contextos locais. Para além desses aspectos considerados, há artigos que convidam ao diálogo com o ensino de diferentes áreas e o nível Médio de ensino.

Temos certeza de que essa edição traz um vasto material que poderá subsidiar muitos diálogos outros com quem se (pre)ocupa com as questões inerentes à educação básica e, mais especificamente, com o Ensino Médio. Assim, convidamos cada leitor a conhecer a apresentação desta edição por meio das palavras que se seguem a essas páginas, escritas pelos professores que organizaram este dossiê.

Para encerrar a escrita deste editorial, dedicaremos dois parágrafos que, cada um da sua forma, nos remete às nossas memórias.

O primeiro deles dialoga com o prazer de ler, com o encantamento que saem dos livros de história e que encantaram estudantes nos anos iniciais do CAp-UERJ, por anos e que, ainda hoje, mesmo depois de terem concluído suas trajetórias escolares no CAp, ainda lembram daqueles encantamentos. Com a "certeza da eterna presença da vida que foi...", relembrando Gonzaguinha (como lembrar dela sem lembrar de Gonzaguinha?), Leila Medeiros de Menezes, a tia Leila para muitos, foi se encantar, de 
DOI: $10.12957 /$ e-mosaicos.2020.53061

uma forma diferente da que encantou seus alunos com as leituras embaixo da mangueira de uma antiga sede do CAp, ou mesmo por entre as almofadas e o tapete do Clube de Leituras Paula Saldanha. A Professora Leila, que tanto contribuiu para a escrita da história do Instituto de Aplicação Fernando Rodrigues da Silveira, a nossa homenagem.

Neste segundo parágrafo, nosso arquivo de memória se ancora no contexto de publicação da edição 19, que traz a parte I deste dossiê temático. Naquela época, não era possível imaginar que estaríamos dando continuidade a esse trabalho num contexto em que o isolamento e o distanciamento social se tornaram necessários e estratégia para mantermos a saúde e preservarmos vidas. Um contexto em que cada um de nós está se reinventando e possibilitando novos reinventares, por meio das tecnologias da comunicação e informação e pelas formas de estarmos e sermos no mundo. Desejamos que isso tudo não demore mais tanto tempo a passar. Mas que, ao entrarmos na chamada nova normalidade, possamos fazer com segurança para a vida de cada um de nós e certos da necessidade de que, nesse movimento de reinvenção, sejamos capazes de reinventar... um outro mundo possível!

E parafraseando Gonzaguinha, nós acreditamos na rapaziada e levamos fé na fé da moçada. Com essa fé e com a certeza de que tudo passará e ficará bem, desejamos aos nossos leitores uma ótima leitura e o convite para colaborarem conosco na divulgação de e-Mosaicos.

Río de Janeíro, Outono de 2020

Andrea da Paíxão Fernandes

Lincoln Tavares Silva

Editoria

e-Mosaicos - Revista Multidisciplinar de Ensino, Pesquisa, Extensão e Cultura 